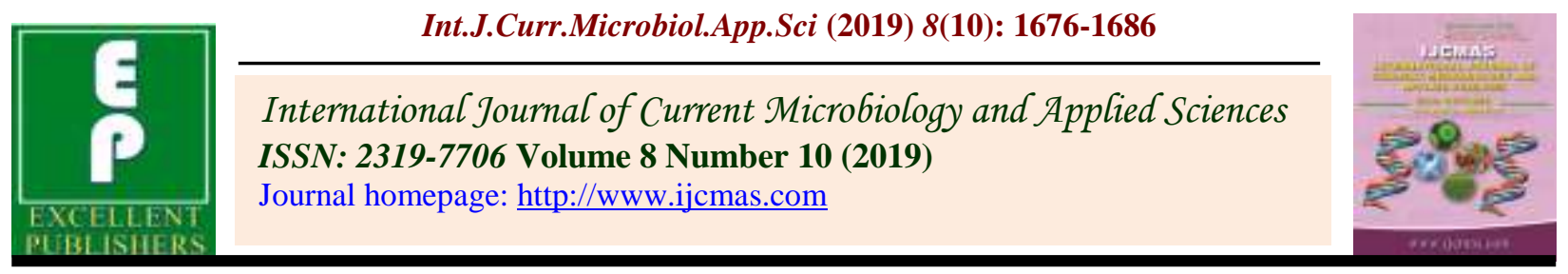

Original Research Article https://doi.org/10.20546/ijcmas.2019.810.195

\title{
Studies on Response of Broilers to Diet Containing Drumstick (Moringa olifera) Leaf Meal as a Natural Feed Additive on Growth Performance
}

\author{
P. B. Meshram, R. A. Patil, P. V. Padghan, A. K. Parade, \\ S. S. Shinde* and B. S. Gaikwad \\ Department of Animal Husbandry and Dairy Science, College of Agriculture, Latur, India \\ *Corresponding author
}

Keywords

Growth

performance, Feed

intake, Feed

conversion ratio,

Economics

\section{Article Info}

Accepted:

12 September 2019

Available Online:

10 October 2019

\section{A B S T R A C T}

A study was conducted to study the effect of drumstick leaf meal as a natural feed additive on growth performance, feed intake and feed conversion ratio and economics of broiler chicken. A Eighty, day-old broiler chicks (Vencob-430) were randomly weighed and assigned to four dietary treatments having 20 birds in each dietary treatment consist of four replicates of 5 birds were reared in deep litter system. Chicks were distributed in 3 different inclusion levels of Moringa olifera leaf meal diets $0.5 \%, 1.0 \%, 1.5 \%$ with 1 control diet. The birds were fed the experimental diets and water was provided without restriction throughout the experimental period. The results showed that significant $(\mathrm{P}<0.05)$ effect on final body weight and weight gain feed intake and feed conversion ratio in dietary feeding of $0.5 \%$ MOLM as compared to that of standard broiler ration (control group). The better feed conversion ratio (1.70) was observed at $0.5 \%$ MOLM group and the different levels of MOLM exhibit significant influence on growth performance of broilers. It is concluded that $0.5 \%$ MOLM in broiler diets can be used as natural feed additive for enhancing growth performance, feed intake and feed conversion and enhanced the cost of broilers.

\section{Introduction}

Indian economy majorly contributed by livestock and poultry sector. Chicken rearing is one of the most suitable activities to improve the livelihoods of the poor due to the advantage it has in terms of the small amount of capital required and the relative ease to setup such a production system in the rural communities. During last three decades the poultry sector has emerged as the fastest growing segment of agriculture in India. All around efforts have been made to achieve this development. The total poultry production in country is 729.2 million. India is emerging as the worlds $2^{\text {nd }}$ market with annual growth rate of more than 14 per cent producing 6 million tones or 3.6 per cent of global egg production. The annual growth rate of egg production is 5 8 per cent apart from this, India ranks $6^{\text {th }}$ in 
poultry production (Anonymous, 2012). The contribution of poultry industry to the national economy is around Rs. 11000/- corers. Poultry industry provides employment to 20 lakh person either directly or indirectly. India has now achieved $5^{\text {th }}$ position in total egg production and $15^{\text {th }}$ place in poultry meat production. Feed additives are added to broilers diet to improve its productive performance by increasing growth rate, better feed conversion efficiency and greater livability in poultry birds. Vegetables as an additive in the diet of chickens are very common. Moringa olifera which belongs to the family Moringaceae, is widespread throughout the tropics. Moringa (Moringa olifera) is a multipurpose tropical tree. It is mainly used for food and has numerous industrial, medicinal and agricultural uses, including animal feeding. Nutritious, fastgrowing and drought-tolerant, this traditional plant was rediscovered in the 1990s and its cultivation has since become increasingly popular in Asia, where it is among the most economically valuable crops. It has been dubbed the "Miracle tree" or "tree of life" by the media (FAO 2014; Radovich, 2013; Orwa et al., 2009). The plant is cited by a number of names such as horseradish tree, drumstick tree, bean oil tree, and a lot more others.

The herbal growth promoters for poultry can create optimum condition for normal vigorous growth by acting various ways. The dietary use of herbal growth promoter increases the performance of broiler by increasing live weight gain and FCR. Epidemiological studies have specified that Moringa olifera leaves are a good source of nutrition and display antitumor, anti-inflammatory, anti-ulcer, antifungal, anti-cholesterol. It improves FCR and enhances immune response of birds. The herbal growth promoters for poultry can create optimum condition for normal vigorous growth by acting various ways. The successful use of herbal growth promoter will fetch more profit to poultry farmer by efficient conversion of feed consumed to body constituents. Moringa is a potential plant that could be used to enhance immune response and to improve intestinal health of broiler chicken.

\section{Materials and Methods}

Eighty, day old, commercial straight run broiler chicks (Vencobb-430) strain was obtained from Huma-hatcheries, Latur (Maharashtra). All the experimental chicks were individually weighed and banded and then randomly distributed in to four treatments of 20 chicks with four replication of 5 chicks in each treatment on similar body weight basis. All the experimental chicks were reared for 42 days on deep litter system in a wellventilated shed. Proper brooding of chicks was done by providing sufficient heat and light by using electric bulbs in each treatment for first three weeks of age. The standard temperature of brooding was $32-35^{\circ} \mathrm{C}$ for first week.

A weekly reduction of $3^{0} \mathrm{C}$ was done till brooder temperature reaches to $27^{\circ} \mathrm{C}$ by third week of age. Afterword, sufficient artificial light was provided during night hours throughout the experimental period. Fresh, clean and cool drinking water was provided to bird's ad-labitum.

All the precautionary measures against diseases were taken throughout the experimental period of six weeks. The dietary treatments $T_{1}-100$ parts of standard broiler ration without supplement (control sample), $\mathrm{T}_{2^{-}}$99.5 parts of standard broiler ration +0.5 Parts of drumstick leaf meal, $\mathrm{T}_{3^{-}} 99.00$ parts of standard broiler ration +1.00 Parts of drumstick leaf meal and $\mathrm{T}_{4}-98.5$ part standard broiler ration +1.5 Parts of drumstick leaf meal. All the broiler chicks were fed with ground maize first two days of age. Chicks feed standard feed purchased from market for three periods of 2-10 days birds fed with pre- 
starter, 11-21 days birds fed with broiler starter and 22-42 days birds fed with broiler finisher. The diets were fed ad-libitum to experimental groups by adding required amount of Moringa olifera leaf meal as per treatment. The per cent ingredient composition of experimental broiler ration that is for prestarter, starter and finisher in Table 1 respectively.

\section{Parameters of feedlot}

\section{Feed intake (g)}

The feed was weighed every week to determine the average feed intake per chick for the different treatment groups. Feed intake was calculated by the remained feed and divided by the number of birds in each group per day and totalized to be per week.

Feed Intake $=$ Introduced parts of food Residual parts of food

\section{Weight gain (g)}

The birds were weighed every week to determine the average weight gain per chick for the different treatment groups. Weight gain was calculated as the difference between two successive weekly body weights as follows.

Weight Gain $=$ Final weight - Initial weight

\section{Feed conversion ratio}

It was recorded at weekly interval and calculated by dividing the total amount of feed consumed by body weight gain for each week.

\section{FCR}

Cumulative feed intake ( $\mathrm{g}$ )

Cumulative live weight gain (g)

(Note: The value excludes the initial weights).

\section{Chemical analysis}

The chemical analysis of the experimental broiler ration were carried out as per A.O.A.C. (1995) for all the proximate principles.

\section{Statistical analysis}

The treatment wise data on cumulative body weight gain in body weight, feed consumption and feed conversion ratio, water intake and blood serum constituents were subjected to analysis of variance of completely randomized design (Snedecor and Cochran, 1982).

\section{Results and Discussion}

\section{Gain in body weight}

The statistical analysis on the weekly body weight of broiler birds under four different treatments during each week revealed significant $(\mathrm{P}<0.05)$ difference during all the weeks except initial, first and second week. After the sixth week it was observed that the average cumulative body weights of broiler birds in the treatment group $\mathrm{T}_{2}$ were significantly $(\mathrm{P}<0.05)$ higher as compared to control in $\mathrm{T}_{1}$ and $\mathrm{T}_{4}$ group where as at par with $T_{3}$. The average body weight of obtained in $T_{2}$ group was significantly superior over $\mathrm{T}_{3}$ and those in $T_{4}$ group. The growth pattern indicated that optimum beneficial effect of Moringa olifera leaf meal supplementation as an herbal feed additive could be achieved at 0.5 per cent level of inclusion. In the present study, the effect of supplementation of MOLM was evaluated, it was found that addition of $0.5 \%$ moringa leaf meal in broiler ration exhibited better weight gain than without moringa leaf meal. It may be due to the presence of the fatty acids, or due to stimulating effect on the digestive system of broilers. The birds fed $0.5 \%$ Moringa olifera leaf meal recorded significantly $(\mathrm{P}<0.05)$ higher mean weight gain compared to control 
and other treatment groups, however, slightly reduced mean body weight gain was observed in $\mathrm{T}_{3}$ group fed 1\% Moringa olifera leaf meal (2533.22 g) Table 2.

The results of the present study were more or less similar trends obtained by Onunkwo and George. (2015) and Banjo (2012) they reported that performance of inclusion of Moringa olifera leaf meal in the diet of broilers significantly $(\mathrm{P}<0.05)$ enhanced body weight gain at $1 \%$ level than control. The reason for the improved weight gain can be attributed to high protein of Moringa olifera leaf meal as claimed by Kakengi et al., (2007). More or less similar findings was also noticed by Omer and Hyder, (2016) they reported that the inclusion of Moringa olifera based diet performed significantly $(\mathrm{P}<0.05)$ better than the birds of control group in terms of higher weight gain.

The present study are in accordance with Gadzirayi et al., (2012) observed that birds fed on Moringa olifera leaf powder gained significantly higher body weights than birds fed the control diet. Okafor et al., (2014) who observed that Moringa olifera supplemented groups recorded a higher daily weight gain. The addition of Moringa olifera seed powder also had significant beneficial effects on weight gain in broilers reported by Talha and Mohamed (2012).

The supplementation of Moringa olifera to broiler feeds might positively affect the growth performance and weight gain. The performance of birds fed Moringa olifera based diet it content rich quantity of nutrients and antimicrobial properties of Moringa olifera may be responsible for gain in body weight. Moringa olifera have a natural enzyme which aid digestion of fibrous food in broilers, also it has a great potential in improving nutrition and strengthening immune functions of broiler chickens.

\section{Feed intake}

The data on the feed consumption of experimental broiler birds under various experimental treatments recorded during the six weeks period were subjected to CRD and the results are presented in Table 3 . It may be seen that there were significant differences among the all treatment groups except first and second week, where significantly differences were recorded after third week up to end of experiment. At the end of experiment the total feed consumed by different treatment groups broiler chicks as $\mathrm{T}_{2}$ group consumed significantly $(\mathrm{P}<0.05)$ lower quantity of feed (4395.16 g) as compared to control $\mathrm{T}_{1}(4715.28 \mathrm{~g})$ where as at par with $\mathrm{T}_{3}$ (4463.73 g) and $\mathrm{T}_{4} 4407.24 \mathrm{~g}$ ). On the perusal of Table 5 it could be seen that lowest feed consumption of $4395.16 \mathrm{~g}$ was obtained in $\mathrm{T}_{2}$ group broilers receiving 0.5 per cent MOLM followed by $4407.24 \mathrm{~g}$ with in $\mathrm{T}_{4}, 4463.73 \mathrm{~g}$ in $\mathrm{T}_{3}$ and highest feed consumption i.e. $4715.28 \mathrm{~g}$ in $\mathrm{T}_{1}$ control at the end of $6^{\text {th }}$ week. It showed that the birds fed with graded level of Moringa olifera leaf meal had lowest feed consumption rate in the broiler birds and achieved more weight gain than without MOLM.

Whereas, Tesfaye et al., (2013) reported that the addition of 10-20\% of Moringa resulted in a significant $(\mathrm{P}<0.05)$ reduction in feed intake as compare to control. However, Atuahene et al., (2013) found no significant influence of Moringa leaf meal diet upto $7.5 \%$ on broilers feed intake. Hence, the other findings by the Mariam et al., (2017) reported an inclusion of the higher levels of Moringa leaves in the diet (P>10\%) led to reduction in the average feed cost. The reduced intake of diet treatment recorded due to high crude fibre content which may invariably reduce palatability Kakengi et al., (2007). Furthermore, Onunkwo and George, (2015) reported that there was not statistically significant difference $(\mathrm{P}<0.05)$ in 
feed consumption of feeding MOLM but numerically lower significant as compared to control. Present result agreed with that estimated by Gakuya et al., (2014) they reported that a reduction in broiler feed consumption $(\mathrm{P}<0.05)$ with the dietary inclusion of moringa in the diet. Banjo, (2012) reported that Moringa olifera leaf meal at $0 \%$, $1 \%, 2 \%$ and $3 \%$ did not significantly enhance feed intake. These variations observed may be due to different level used. Then the similar result of improving the feed consumption by Donkor et al., (2013) reported that the addition of MOLM to poultry feed leaf to high output performance in poultry production. The present result obtained are contrary agreement with Ochi et al., (2015) who reported that during finisher and the whole period supplying broiler chicks diet with $0.5 \%$ Moringa olifera seed powder resulted in significant increase in feed consumption. Similar reports are available in the literature by Okafor et al., (2014) observed that a diet contained a $20 \%$ replacement level of Moringa olifera leaf protein concentrate for soybean meal did not found to alter the weekly feed intake in broilers. Gadzirayi et al., (2012) investigated the effects of supplementing soya bean meals with Moringa olifera leaf meal (25\%, 50\%, $75 \%$ and $100 \%$ ) as a protein source in poultry and found no significant differences in feed intake of broilers. Contradictory results were also observed by Atuahene et al., (2008) and reported that no-significant $(\mathrm{P}>0.05)$ effect of diets containing MOLM at $0 \%, 2.5 \%, 5 \%$ and $7.5 \%$ levels on feed intake of broilers chickens. Similar results are disagree with Aderinola et al., (2013) reported the control diet had the lower total feed intake and weight gain as compared to all the treatment groups.

Leaf meals are generally bitter in taste, therefore, the inclusion of MOLM in the diets could have resulted in reduced palatability and thus reduce feed intake of the broiler diets. Moringa olifera is a plant that can meet $a l$. ,most all the nutritional needs of the body, because it contains $29.6 \%$ protein, 48 antioxidants, 18 amino acids, vitamins and minerals. Compounds contained in Moringa olifera can stimulate the bile duct wall secrete bile and stimulate the release of pancreas sap to improve the digestion of feed ingredients Onunkwo and George, (2015).

\section{Feed conversion ratio}

The mean weekly feed conversion ratio in terms of feed intake per unit gain in weight for different dietary groups during $1^{\text {st }}$ to $6^{\text {th }}$ week were calculated from following the data. It was revealed from Table 4.

That the best feed conversion ratio of 1.70 obtained in $\mathrm{T}_{2}$ group broilers receiving 0.5 per cent Moringa olifera leaf meal followed by 1.75 with 1.5 per cent in $\mathrm{T}_{4}, 1.76$ in $\mathrm{T}_{3}$ group receiving 1 per cent Moringa leaf meal and poor in feed conversion i.e. 1.95 in $\mathrm{T}_{1}$ control at the end of $6^{\text {th }}$ week. It showed that the 0.5 per cent level of Moringa olifera leaf meal give better feed conversion ratio in broiler birds. Our result in feed conversion ratio of the birds fed moringa leaf meal based diets showed similarity with the result with Ochi et al., (2015) observed more or less similar observation with present study who reported that broiler chicks fed with $0.5 \%$ Moringa olifera seeds powder has significantly reduction in feed conversion ratio. Similar results with Sarker et al., (2017) who reported that the significantly lowest feed conversion ratio was observed at $1.5 \%$ MOLM fed the dietary group. The present results are in agreement with David et al., (2012) reported that replacing antibiotic growth promoters with herbal supplements $0.1 \%$ and $0.05 \%$ Moringa leaf powder has beneficial effects on the feed conversion ratio. The present findings are in related with Kout et al., (2015) who reported that best feed conversion ratio in birds fed on $0.2 \%$ MOLM. 
Table.1 Chemical composition of experimental broiler ration

\begin{tabular}{|l|l|l|l|l|}
\hline Sr.No. & \multirow{2}{*}{ Per cent in ration } \\
\cline { 3 - 5 } & Nutrients & Pre-starter & Starter & Finisher \\
\hline $\mathbf{1}$ & Crude protein & 23.35 & 21.64 & 20.20 \\
\hline $\mathbf{2}$ & Crude fibre & 3.92 & 3.96 & 3.99 \\
\hline $\mathbf{3}$ & Ether extract & 4.95 & 5.08 & 5.12 \\
\hline $\mathbf{4}$ & Total ash & 6.2 & 6.1 & 5.93 \\
\hline $\mathbf{5}$ & Acid insoluble ash & 1.57 & 1.60 & 1.62 \\
\hline $\mathbf{6}$ & Nitrogen free extract & 61.58 & 63.22 & 64.76 \\
\hline $\mathbf{7}$ & Metabolizable energy $(\mathrm{kcal} / \mathrm{kg})$ & 2982.5 & 3065.7 & 3198.8 \\
\hline $\mathbf{8}$ & E/P ratio & $127.73: 1$ & $141.66: 1$ & $158.35: 1$ \\
\hline
\end{tabular}

Table.2 Average weekly gain in body weight $(\mathrm{g})$ per bird

\begin{tabular}{lcccccc}
\hline Items & \multicolumn{7}{c}{ MOLM levels } \\
\cline { 2 - 7 } & $\mathbf{T}_{\mathbf{1}}$ & $\mathbf{T}_{\mathbf{2}}$ & $\mathbf{T}_{\mathbf{3}}$ & $\mathbf{T}_{\mathbf{4}}$ & & \\
\hline $1^{\text {st }}$ week & 119.03 & 111.68 & 112.10 & 110.78 & 8.94 & NS \\
\hline $2^{\text {nd }}$ week & 196.00 & 197.25 & 195.50 & 196.50 & 26.37 & NS \\
\hline $3^{\text {rd }}$ week & 320.25 & 478.42 & 455.25 & 441.70 & 24.08 & NS \\
\hline $4^{\text {th }}$ week & $532.25^{\mathrm{b}}$ & $488.33^{\mathrm{a}}$ & $481.25^{\mathrm{a}}$ & $509.79^{\text {ab }}$ & 9.77 & $*$ \\
\hline $5^{\text {th }}$ week & $609.78^{\mathrm{a}}$ & $659.69^{\mathrm{b}}$ & $620.00^{\mathrm{a}}$ & $591.25^{\mathrm{a}}$ & 10.47 & $*$ \\
\hline $6^{\text {th }}$ week & 648.98 & 644.30 & 669.12 & 665.76 & 27.50 & NS \\
\hline Total & $2426.28^{\mathrm{a}}$ & $2579.66^{\mathrm{b}}$ & $2533.22^{\mathrm{b}}$ & $2515.77^{\text {ab }}$ & 32.96 & $*$ \\
\hline (Significant (P<0.05) means under each class in the same column with different superscripts differ significantly)
\end{tabular}

(Significant $(\mathrm{P}<0.05)$ means under each class in the same column with different superscripts differ significantly) 
Table.3 Feed intake of broiler chicks as affected by addition of moringa olifera leaf meal

\begin{tabular}{lcccccc}
\hline Items & \multicolumn{6}{c}{ MOLM levels } \\
\cline { 2 - 7 } & $\mathbf{T}_{\mathbf{1}}$ & $\mathbf{T}_{\mathbf{2}}$ & $\mathbf{T}_{\mathbf{3}}$ & $\mathbf{T}_{\mathbf{4}}$ & & \\
\hline & $0 \%$ & $0.5 \%$ & $1 \%$ & $1.5 \%$ & SE & CD at $5 \%$ \\
\hline $1^{\text {st }}$ week & 138.76 & 121.32 & 124.58 & 126.33 & 7.83 & NS \\
\hline $2^{\text {nd }}$ week & 341.04 & 308.70 & 334.00 & 339.30 & 12.50 & NS \\
\hline $3^{\text {rd }}$ week & $726.82^{\mathrm{c}}$ & $711.55^{\mathrm{b}}$ & $682.40^{\mathrm{a}}$ & $664.95^{\mathrm{a}}$ & 9.59 & $*$ \\
\hline $4^{\text {th }}$ week & $1135.72^{\mathrm{b}}$ & $1004.20^{\mathrm{a}}$ & $1015.90^{\mathrm{a}}$ & $1073.81^{\mathrm{ab}}$ & 22.70 & $*$ \\
\hline $5^{\text {th }}$ week & $1117.17^{\mathrm{d}}$ & $1075.66^{\text {cd }}$ & $1054.41^{\text {bc }}$ & $972.35^{\mathrm{a}}$ & 18.36 & $*$ \\
\hline $6^{\text {th }}$ week & $1255.77^{\mathrm{d}}$ & $1174.15^{\mathrm{a}}$ & $1252.44^{\text {cd }}$ & $1230.50^{\text {bc }}$ & 13.71 & $*$ \\
\hline Total & $4715.28^{\mathrm{b}}$ & $4395.16^{\mathrm{a}}$ & $4463.73^{\mathrm{a}}$ & $4407.24^{\mathrm{a}}$ & 38.86 & $*$ \\
\hline
\end{tabular}

(Significant $(\mathrm{P}<0.05)$ means under each class in the same column with different superscripts differ significantly)

Table.4 Average weekly feed conversion ratio of experimental birds

\begin{tabular}{lllllll}
\hline Items & \multicolumn{6}{c}{ MOLM levels } \\
\cline { 2 - 7 } & $\mathbf{T}_{\mathbf{1}}$ & $\mathbf{T}_{\mathbf{2}}$ & $\mathbf{T}_{\mathbf{3}}$ & $\mathbf{T}_{\mathbf{4}}$ & & \\
\hline & $0 \%$ & $0.5 \%$ & $1 \%$ & $1.5 \%$ & $\mathrm{SE}$ & CD at $5 \%$ \\
\hline $1^{\text {st }}$ week & 1.17 & 1.08 & 1.11 & 1.14 & 0.26 & $\mathrm{NS}$ \\
\hline $2^{\text {nd }}$ week & $1.74^{\mathrm{b}}$ & $1.56^{\mathrm{a}}$ & $1.71^{\mathrm{b}}$ & $1.72^{\mathrm{b}}$ & 0.02 & $*$ \\
\hline $3^{\text {rd }}$ week & $2.27^{\mathrm{b}}$ & $1.48^{\mathrm{a}}$ & $1.49^{\mathrm{a}}$ & $1.50^{\mathrm{a}}$ & 0.02 & $*$ \\
\hline $4^{\text {th }}$ week & 2.14 & 2.05 & 2.10 & 2.10 & 0.04 & $\mathrm{NS}$ \\
\hline $5^{\text {th }}$ week & $1.83^{\mathrm{b}}$ & $1.63^{\mathrm{a}}$ & $1.70^{\mathrm{a}}$ & $1.64^{\mathrm{a}}$ & 0.02 & $*$ \\
\hline $6^{\text {th }}$ week & 1.96 & 1.82 & 1.87 & 1.84 & 0.05 & $\mathbf{N S}$ \\
\hline Total & $1.95^{\mathrm{b}}$ & $1.70^{\mathrm{a}}$ & $1.76^{\mathrm{a}}$ & $1.75^{\mathrm{a}}$ & 0.03 & $*$ \\
\hline
\end{tabular}

(Value with no common superscript are significantly different $(\mathrm{P}<0.05)$ within a column) 
Table.5 Economics of broiler production per bird

\begin{tabular}{|c|c|c|c|c|}
\hline \multirow[t]{2}{*}{ Particular } & \multicolumn{3}{|c|}{ MOLM levels } & \multirow[b]{2}{*}{$\mathrm{T} 4$} \\
\hline & $\mathrm{T} 1$ & $\mathrm{~T} 2$ & $\mathrm{~T} 3$ & \\
\hline Cost of day old chicks (Rs.) & 45 & 45 & 45 & 45 \\
\hline Moringa consumed per bird (g) & 0 & 10.98 & 22.31 & 33.05 \\
\hline Cost of Moringa (₹/g) & 0 & 0.24 & 0.24 & 0.24 \\
\hline Cost of Moringa (Rs.) & 0 & 2.64 & 5.35 & 7.93 \\
\hline Avg. Total feed consumed per bird (g) & 4715.28 & 4395.16 & 4463.73 & 4407.24 \\
\hline Cost of feed (₹ /Kg) & 28.9 & 28.9 & 28.9 & 28.9 \\
\hline Cost of feed consumed per bird & 136.27 & 127.02 & 129.00 & 127.37 \\
\hline Total cost of feed consumed per bird ₹ & 136.27 & 129.66 & 134.35 & 135.3 \\
\hline $\begin{array}{l}\text { Avg. Body weight gain at the end of } \\
6^{\text {th }} \text { week (g) }\end{array}$ & 2426.28 & 2579.66 & 2533.22 & 2515.77 \\
\hline Feed consumption per kg live weight $(\mathrm{g})$ & 1943.42 & 1707.78 & 1762.08 & 1751.85 \\
\hline Cost of feed per kg live weight gain $(₹)$ & 56.17 & 49.24 & 50.92 & 50.63 \\
\hline $\begin{array}{l}\text { Cost of medicine, vaccine and litter } \\
\text { material per bird (₹) }\end{array}$ & 6 & 6 & 6 & 6 \\
\hline $\begin{array}{l}\text { Cost of Production per bird (₹) } \\
186.3\end{array}$ & 187.27 & 180.86 & 185.35 & \\
\hline $\begin{array}{l}\text { Avg. Price realized @ ₹ } 90 \text { Per kg live } \\
\text { weight (₹ ) }\end{array}$ & 208.60 & 215.33 & 211.56 & 210.08 \\
\hline Net profit per bird (14-13) ₹ & 21.33 & 34.67 & 26.21 & 23.78 \\
\hline
\end{tabular}

The result was line with finding of Egu, (2019) who observed that the MOLM showing best feed conversion ratio as compared to without MOLM diet.

Onunkwo and George et al., (2015) reported significant decrease in the feed conversion ratio of the birds fed MOLM levels 0.0\%, $5.0 \%, 7.5 \%$ and $10 \%$ based diets.
The present result was in accordance with Banjo, (2012) the inclusion of Moringa olifera leaf meal at $1 \%, 2 \%$ and $3 \%$ in the diet did not significantly enhance feed conversion ratio. The present results obtained are contrary to the findings of Aderinola et al., (2013) who illustrated that using (MOLM) $(0 \%, 0.5 \%$, $1.0 \%, 1.5 \%$ and $2.0 \%$ ) as a feed supplement results revealed that control diet had higher feed conversion ratio than Moringa olifera 
leaves meal based diets.

Moringa olifera has beneficial antiinflammatory and antioxidants properties. Moringa olifera contains vitamins (A, E, B $\mathrm{B}_{2}$, $\mathrm{B}_{5}, \mathrm{~B}_{6}$, folic acid) and minerals $(\mathrm{Ca}, \mathrm{Fe})$ Moringa has strong fungicidal and antimicrobial activity also an anti-blood cholesterol effect. Moringa improves FCR and enhance immune response of birds. Also, its leaves have neutral antioxidant compounds and soluble protein. The results showed that the Moringa olifera had the capacity of improving efficiency of feed utilization level. The efficient utilization of feed resulted in the highest body weight gain were observed in broilers. Broiler chicks can tolerate up to $0.5 \%$ MOLM in the diet without any adverse effect.

\section{Economics of broiler production}

The economic profit was calculated according to both market price of one-kilogram of feed and the prevailing market price of onekilogram live bird weight at 42 days of age. The dada illustrated in Table 5 indicated that feeding MOLM increased the economic profit, especially with group received $0.5 \%$ MOLM compared with the control diet. The profit was estimated by considering total amount of feed consumed by broilers under $\mathrm{T}_{1}$ control and Moringa olifera leaf meal fed groups. Other factors such as cost of day old chicks, medicine, vaccines and litter material were common for all the treatments and control groups. However, the cost of labors, electricity, etc. was not considered in calculating the economics of broiler production, being the post graduate research work. The data regarding average live body weight (g), average feed consumption (g), feed consumption per kg live weight gain, cost of feed (Rs.), total cost of feed (including cost of moringa leaf meal used per $\mathrm{kg}$ of feed under different treatments), cost of feed per kg live weight gain and net profit per bird are given in
Table 2. The net profit per bird was highest in $\mathrm{T}_{2}$ (Rs 34.67), followed by $\mathrm{T}_{3}$ (Rs 26.21), $\mathrm{T}_{4}$ (Rs 23.78) and lowest for $\mathrm{T}_{1}$ control (Rs 21.33). The observation indicated that the performance of broilers in $\mathrm{T}_{2}$ group was superior to that of the control and other treatments and $0.5 \%$ per cent level of Moringa olifera leaf meal diet seems to be economical. This might be due to improved feed conversion efficiency on supplementation of Moringa olifera leaf meal. These results were partially in agreement with Donkor et al., (2013) who recorded that birds fed with $0.5 \%$ addition of Moringa olifera leaves meal to poultry feed will lead to high output performance in poultry production. Marium et al., (2017) also found similar results with this experiment and reported that broilers feeding with $2 \%$ per cent Moringa olifera leaves meal was the most effective for obtaining high returns per bird. More similar observation are recorded by Onunkwo and George, (2015) who reported that the leaf supplementation 10 $\%$ in poultry rations has been proved that the reducing cost and improving profit margin. The economization of feed cost using cheaper and unconventional feed resources is an important aspect of commercial poultry production. The results of economical evaluations of the experimental diets showed that the supplementation of MOLM to broiler diets improved the performance of chicks and resulted economic benefits. Considering the results, it may be concluded that inclusion of Moringa olifera leaves in diet of broiler chickens is a real opportunity for stockholders to enhance their income by improving the productivity. The addition of the Moringa olifera leaves to poultry feed will lead to high output performance in poultry production.

This study indicated that supplementation of moringa leaf meal at the difference levels of $0.5 \%, 1.0 \%$ and $1.5 \%$ in the broiler chick's diet. The inclusion of 0.5 per cent of moringa leaf meal in broiler diet as a herbal feed 
supplement is beneficial in improving the live weight, weight gain feed consumption and feed conversion ratio. The feeding of Moringa olifera leaf meal is economical as it improved overall performance of broilers and increased margin of profit in broiler production. The feeding of moringa leaf meal is beneficial as a growth promoter or feed supplement in commercial broiler production.

\section{References}

Aderinola O. A., Rafiu T. A., Akinwumi A. O., Alabi T. A. and Adeagbo O. A. (2013). Utilization of Moringa oleifera Leaf as Feed Supplement in Broiler Diet. International Journal of Food, Agriculture and Veterinary Sciences, 3(3): 94-102.

Akinola L. A. and Ovotu N. (2018). Influence of Moringa oleifera Leaf Meal on Egg Lipids and Blood Constituents of Laying Hens. International Journal of Experimental Agriculture, 22(2):1-9.

Anonymous (2012). Annual report 2012-2013. Department of Animal Husbandry Dairying, Ministry of Agriculture, Government of India. New Delhi.

A. O. A. C. (1995). Official Methods of Analysis, $16^{\text {th }}$ ed. Association of Official Analytical Chemist, Washington D. C..

Atuahene C. C., Akowuah D. and Adjei M. B. (2013). The Effect of Garlic (Allium sativum) as a Natural Feed Additive on the Growth Performance of Broiler Chickens. International Journal of Scientific and Research Publications, 8(2):541-543.

Banjo O. S. (2012). Growth and Performance as Affected by Inclusion of Moringa oleifera Leaf Meal in Broiler Chicks Diet. Journal of Biology, Agriculture and Healthcare, 2(9):35-45.

David L. S., Vidanarachchi J. K., Samarasinghe S., Cyril H. W. and
Dematawewa C. M. (2012). Effects of Moringa Based Feed Additive Performance and Carcass Quality of Broiler Chick. Tropical Agricultural Research, 24(1):12-20.

Donkar A. M., Glover R. L., Addae D., and Kubi K. A. (2013). Estimating the Nutritional Value of the Leaves of Moringa oleifera on Poultry. Food and Nutrition Science, 4(10):1077-1083.

Egu U. N. (2019). Effect of Graded Levels of Moringa oleifera Leaf Meal on Performance and Serum Biochemical Parameters of Broiler Chickens. Journal of Animal Science and Veterinary Medicine, 4(1):1-8.

FAO 2014. Moringa. Traditional Crop of the Month. FAO

Gakuya D. W., Mbugua P. N., Kavoi B. and Kiama S. G. (2014). Effect of Supplementation of Moringa oleifera Leaf Meal in Broiler Chicken Feed. International Journal of Poultry Science, 13(4):208-213.

Gadzirayi C. T., Masamha B., Mupangwa J. F. and Washaya S. (2012). Performance of Broiler Chickens Fed on Mature Moringa oleifera Leaf Meal as a Protein Supplement to Soybean Meal. International Journal of Poultry Science, 11(1):5-10.

Gujjarwar S. V. (2018). Effect of Ginger (Zingiber officinalis) Powder as a Natural Feed Additive on Growth Performance of Broilers. M. Sc. (Agri.) Thesis, Submitted Marathwada Agriculture University, Parbhani.

Kakengi A. M. V., Kaijage J. T., Sarwatt S. V., Mutayoba S. K., Shem M. N. and Fujihara T. (2007). Effect of Moringa oleifera Leaf Meal as a Substitute for Sunflower Seed Meal on Performance of Laying Hens in Tanzania. Livest Res Rur Dev. 12(4):19:120.

Kout E., Moustafa M. E., L. Riry, Shata F. H., M. A. M. Hanan, Alghonimy A. H. 
and Youssef S. F. (2015). Effect of Using Moringa oleifera Leaf Meal on Performance of Japanese quail. Egypt. Poult. Sci. 35(4): 1095-1108.

Mariam E. A., Afaf A., Faten K., Gehan R., Mohammed N. and Boareki. (2017). Effect of Varying Levels of Moringa as Replacement for Soyabean Meal in Broiler Ration. Kuwait J. Sci., 44(3):96-103.

Ochi E. B., Elbushra M. E., Fatur M., Abubakr O. I. and Hafiz A. (2015). Effect of Moringa (Moringa oleifera L.) Seeds on the Performance and Carcass Characteristics of Broiler Chickens. Journal of Natural Sciences Research, 5(8):66-73.

Okafor I. N., Ezebuo F. C. and Azodo N. T. (2014). Effect of Moringa oleifera Leaf Protein Concentrate Supplemented Feed on Growth and Nutritional Parameters in Broilers. World Applied Sciences Journal, 32(1):133-138.

Omer M. E. and Hyder E. A. (2016). Effect of Feeding Different Levels of Moringa oleifera Leaf Meal on Performance and Some Blood Parameters of Broilers. International journal of science and research, 5(3):632-635.

Onunkwo D. N. and George O. S. (2015). Effects of Moringa oleifera Leaf Meal on the Growth Performance and Carcass Characteristics of Broiler Birds. J. Agri. Vet. Sci., 8(3):63-66.
Orwa C., Mutua A., Kindt R., Jamnadass R., Anthony S. (2009). Agroforestry Database: a Tree Reference and Selection Guide Version 4.0.World Agroforestry Centre, Kenya.

Radovich T. (2013). Farm and Forestry Production and Marketing Profile for Moringa. In Elevitch C.R. (Ed.) Specialty Crops for Pacific Island Agroforestry. Permanent Agriculture Resources (PAR), Holualoa, Hawai.

Sarker S. K., Masud R., Khatun H., Faruque S., Sarker N. R., Sharmin F. and Islam N. (2017). Moringa Leaf Meal as Natural Feed Additives on the Growth Performance and Meat Quality of Commercial Broiler Chicken. Asian J. Med. Biol. Res., 3(2):240-244.

Snedecor G. W. and Cochran W. G. (1982). Statistical Methods. 6th Edition, Oxford and IBH Publishing co. Culcutta, Bombay and Delhi. 168-181.

Talha E. A. and Mohamed E. A. (2012) Use of Moringa oleifera Seeds in Broilers Diet and its Effects on the Performance and Carcass Characteristics. Int J. App Poult Res., 1(1):1-4.

Tesfaye E., Animut G., Urge M. and Dessie T. (2013). Moringa olifera Leaf Meal as an Alternative Protein Feed Ingredient in Broiler Ration. International Journal of Poultry Science, 12(5):289297.

\section{How to cite this article:}

Meshram, P. B., R. A. Patil, P. V. Padghan, A. K. Parade, S. S. Shinde and Gaikwad, B. S. 2019. Studies on Response of Broilers to Diet Containing Drumstick (Moringa olifera) Leaf Meal as a Natural Feed Additive on Growth Performance. Int.J.Curr.Microbiol.App.Sci. 8(10): 1676-1686. doi: https://doi.org/10.20546/ijcmas.2019.810.195 